\title{
THE ROLE OF EDUCATIONAL SOCIETIES IN THE DEVELOPMENT OF EDUCATION IN ELISAVETGRAD REGION: SECOND HALF OF XIX- EARLY XX CENTURY
}

\begin{abstract}
Olena Olizko ${ }^{1}$
graduate student of the Department of Pedagogy and Education Management, Volodymyr Vynnychenko Central Ukrainian State Pedagogical University, Kropyvnytskyi, Ukraine, e-mail: olizko.lena@ukr.net, ORCID: https://orcid.org/0000-0001-6284-5461
\end{abstract}

\begin{abstract}
The article reveals the role of educational societies of Yelisavetgrad region in the development of education in the region in the second half of the XIX - early XX century. The purpose of the article is to reveal the role of educational societies of Yelisavetgrad region in the development of education in the region in the second half of the XIX-early XX century. The publication uses a historical-retrospective method, which allows for a retrospective analysis of the history of educational societies of Yelisavetgrad region in the period under study and highlight their contribution to the development of education in the region. It was found that a significant contribution to the development of educational processes in the Yelisavetgrad region in this period was made by educational societies opened on the initiative of progressive public figures of the city. Among the greatest achievements of Yelisavetgrad charity in providing various segments of the population with both basic and special knowledge is the rich and diverse activity of the Yelisavetgrad Society for Literacy and Crafts, which on a charitable basis carried out large-scale educational, pedagogical and educational work: progressive literature, conducted significant educational and organizational and advocacy work among the population and students of educational institutions, organized theater performances, concerts, art exhibitions. Through the efforts of the society, a home for young homeless children, the first kindergartens, a free public library-reading room and a public library were opened in the city.

Active educational and propaganda activities of the members of the society played a leading role in the spread of education among various segments of the population, contributed to the development of schooling in the region. N. Braker, P. Ryabkov, M. Fedorovsky, V. Khartsiev and others made a significant contribution to reviving the work of the society.
\end{abstract}

Key words: cultural and educational societies, Yelisavetgrad society of literacy and handicrafts, educational activity, public initiatives, educational institutions.

JEL Classification: JEL I0; I20

Formulas: 0; fig.: 0; tabl.: 0; bibl.: 12

Introduction. The second half of the XIX - early XX century in the Ukrainian lands of the Russian Empire is intensifying charitable, philanthropic movement, due to the development of capitalist relations and the formation of the entrepreneurial stratum, which was the social force that potentially provided material conditions for philanthropy and philanthropy. The second half of the 19th and the beginning of the 20th centuries was a period of creation and rapid development of a large number of public associations, organizations and societies, which played a role in all spheres of public life of the country. These organizations were created to address issues of educational, pedagogical, educational nature.

One of the characteristic features of the social and pedagogical movement in the Yelisavetgrad region in the second half of the XIX century was the creation of cultural and educational societies. Due to the democratization of society during this period, various societies emerged, which aimed to provide education to the common people of the region and were the bearers of a new, pedagogical ideology. One such 
association was the Yelisavetgrad Society for the Promotion of Literacy and Crafts, one of the leading societies in the Russian Empire during the study period.

Literature review. The source base of the study was the annual reports, constituent documents of the Yelisavetgrad Society for the Dissemination of Literacy and Crafts, which are stored in the State Archives of Kirovohrad region. Also significant scientific and historical information is contained in the works of public figures of the pre-revolutionary period N. Braker [4], P. Ryabkova [8].

A significant role in the actualization of the research problem was played by the works of local lore of modern researchers O. Akimkin [1], V. Boska [3], I. Bosa [2], O. Trybutska [9], O. Filonenko [10; 11], L. Filoretova [12] and others, in which the authors, analyzing the educational activities of members of the Yelisavetgrad Society for Literacy and Crafts, also note the place and role of M. Fedorovsky in the development of educational institutions and public education system in Yelisavetgrad region. At the same time, the pedagogical and public-educational activity of the Yelisavetgrad Society for the Dissemination of Literacy and Crafts and its members, which carried out large-scale educational, pedagogical and educational work on a charitable basis, contributed to the establishment of educational institutions.

The relevance of the chosen topic is exacerbated by the contradictions between the accumulated theoretical ideas and experience of public education and pedagogical activities of members of the Yelisavetgrad Society for Literacy and Crafts and the lack of their scientific understanding, generalization and systematization for creative use by modern teachers.

Aims. The purpose of the article is to reveal the role of educational societies of Yelisavetgrad region in the development of education in the region in the second half of the XIX - early XX century.

Methods. The publication uses a historical-retrospective method, which allows for a retrospective analysis of the history of educational societies of Yelisavetgrad region in the period under study and highlight their contribution to the development of education in the region.

Results. Among the greatest achievements of Yelisavetgrad charity in providing the common people with both basic and special knowledge is the rich and diverse activity of the Yelisavetgrad Society for the Dissemination of Literacy and Crafts, which was founded in 1873 on the initiative of public and cultural figure and teacher M. Fedorovsky. This aspect combined around him a significant part of the city's intelligentsia and as a result of its activities was one of the most successful in the Russian Empire [2]. Note that the above society in terms of its activities was one of the most successful in the Russian Empire.

The society carried out large-scale educational, pedagogical and educational work on a charitable basis: it promoted the establishment of educational institutions, organized Sunday readings of progressive literature, conducted significant educational and organizational and propaganda work among the population and students, organized theater performances, concerts and art. Through the efforts of the society, a shelter for homeless children, the first kindergartens $(1913 ; 1915)$, a free 
public library-reading room (1895) and a public library (1899) were opened in the city.

The Yelisavetgrad Free Crafts and Literacy School (1867) was under the auspices of the Society for the Dissemination of Literacy and Crafts. with other primary schools it was much better in teaching and other aspects, and craft departments made it generally exceptional among the city or government county schools of that time. [10, p. 89].

In the report on the state of the Yelisavetgrad free craft and literate school for 1884/1885. It was reported that the school had 2 departments - women's and men's, which were located at different addresses: for girls - on the corner of st. Prison and Vokzalna, and for the boys - on the corner of Perspektyvna and Oleksiyivska streets. Each building had its own teachers. At that time, the school had 12 teachers who taught 180 students at that time. [7, p. 54].

The school had only 4 classes, also preparatory classes for older and younger children. They were taught to read and write by the sound method in preparatory classes. In the first class they studied the Law of God, Russian language, arithmetic; in the second class (except the above) geography; in the third - Russian language, Russian history and geometry. All students were engaged in gymnastics and church singing. Subjects such as geography, physics, technology of metals and wood, science, information on the law were studied only in a special men's department.

In the men's department they studied carpentry and turning, in the women's department they taught sewing and knitting. Craft training began at the age of 12. In 1886 , the men's and women's classrooms were merged and the theoretical course was taught together, with separate classes only in the workrooms.

On January 13, 1905, a special men's department and a training workshop were reopened at the Yelisavetgrad Free Crafts and Literacy School. The main task of the special department was to train leaders for training craft departments, which were opened in the villages to raise the material well-being of the population.

Children of all walks of life from the age of 12 to 14 were admitted to the special men's department after taking exams according to the program of the city's primary public schools. Children who completed an educational course in a free craft and literacy school, as well as in urban elementary schools, parish schools and oneclass Jewish schools were admitted to the first grade without exams and upon admission took only a competitive exam in Russian language and arithmetic on a common basis. with entrants who have received home primary education.

The term of study was 5 years, of which 4 years were classes in classrooms and workshops, and in the fifth year only practical classes were held. For the first four years, students practiced from 8 to 12 a.m hours in classrooms, and from 14 to 18 p.m were engaged in the workshops of the school. In the classes taught: the Law of God, Russian language, arithmetic, geometry, national history, geography, mechanics, physics, technology of metals and wood, science, children were given a basic knowledge of the law. Teaching subjects took place in accordance with the programs developed by the executive committee [7, p. 59-62]. 
In the training workshops, children were taught various crafts: carpentry, turning, wood carving, metalwork and blacksmithing. The teaching of these crafts had a practical direction and involved the inculcation of skills and abilities in a particular craft.

After completion of a full five-year course in a special department, graduates had the right to take exams, after which they successfully passed the title of primary school teacher.

Gifted, but poor students were enrolled in full-time education at the expense of the Yelisavetgrad Society for the Dissemination of Literacy and Crafts or were awarded a scholarship.

A school council was established, which met at least once a month to address issues related to the educational part The council compiled subject programs and divided the study of subjects into classes, appointed transfer and final exams, awarded prizes to the best students, compiled annual reports on learning outcomes.

According to numerous archival documents, the Yelisavetgrad Free Craft and Literacy School was the only such craft and literacy school in terms of its type, programs, and teaching skills, not only in Yelisavetgrad, but also in the entire Russian Empire [10, p. 68].

An analysis of the sources shows that the Yelisavetgrad Society for the Dissemination of Literacy and Crafts contributed to the development of handicrafts in the region. In addition to the care of the craft and literacy school, it was engaged in the organization of artel of artisants, the arrangement of warehouses with materials and sales of their products. The financial organization of the artels activities became more important role - loan and savings branches were created for them. The activities of the society were aimed not only at the quantitative expansion of this industry, but also at qualitative changes in it through the publication of books on handicrafts and by exhibiting the products of artisans at various exhibitions $[8, \mathrm{p} .6]$.

A large part of the local intellectuals was a member of the society. Active educational and propaganda activities of the members of the society played a leading role in the spread of education among various segments of the population, contributed to the development of schooling in the region. N. Braker, P. Ryabkov, M. Fedorovsky, and others made a significant contribution to reviving the work of the society.

One of the brightest representatives of the society was its founder Mykola Fedorovich Fedorovsky. Well-known public figure, ethnographer, archaeologist Pavel Zakharovich Ryabkov, analyzing the work of the Yelisavetgrad Society for the Dissemination of Literacy and Crafts, noted that the intensity of educational activities of the society largely depends on its composition, the influence of individuals on the society and its members, between them a special place gave to Fedorovsky: "Mykola Fedorovich, being infinitely devoted to the cause, devoting himself to the craft and literate school, sought to expand the activities of society, to raise its viability; ... with the entrance of M. Fedorovsky from society, his decline becomes especially noticeable "[8, p. 20]. 
"The first Ukrainian figure of our city", a man of "indefatigable energy, broad initiative and strong liberty, who did not want to reckon with any obstacles" - wrote about Mykola Fedorovich his contemporaries [4, p. 3].

Prominent pages were inscribed in the national history and founded by M. Fedorovsky free Yelisavetgrad Crafts and Literacy School (1867), Yelisavetgrad Society for the Dissemination of Literacy and Crafts (1873), and other societies: «Self-help for diseases», «The whole Slavic musical circle for the spiritual uplift of the people», «Society for the publication of useful and cheap books for the Ukrainian people» (books were published in Ukrainian), branches of which were opened in other cities $[4$, p. 46].

The work published by P. Ryabkov on the occasion of the 25th anniversary of the society "A Brief Historical Essay of the Elisavetgrad Society for the Dissemination of Literacy and Crafts" is devoted to the achievements of the society in the sphere of education (1873-1898) [8]. He emphasizes in this work that "only with the assistance of all the Yelisavetgrad intelligentsia and its active support is it possible for the society to work for the benefit of the people's education. I hope that such indifference is not temporary "[8, p. 42].

It should be noted that the society's activity in the public circles caused a rather ambiguous reaction and was criticized in some places. P. Ryabkov, who was its active member for many years, wrote: "The purpose of the society is charity and enlightenment of the people. We will do this necessary and important work, as much as we have enough strength, despite the difficulties, overcoming obstacles "[8, p. 18].

From P. Ryabkov's report we learn that there were both periods of ups and downs in the company's activities. The period of the society's activity from 1878 to 1882 can be called a period of decline and inactivity. The council of the society was not even convened to consider and approve the reports and elect the officials of the Yelisavetgrad Crafts and Literacy School, which was taken care of by the society. In fact, the school functioned independently. However, the activity of the society was resumed in 1882 , but nothing significant was done from 1882 to 1886, none of the initiatives was implemented. Describing the activities of the society during this period, P. Ryabkov said: "This time is one of the gloomy pages in the life of the society, which indicates the low social activity of the Yelisavetgrad intelligentsia of that time, which allowed the decline of society, a single light phenomenon on a dark background of provincial life ..." [8, p. 22].

And only 1894 can be called the year of the real resumption of the society, as P. Ryabkov himself writes: "Since then, the revival of the society begins, it is gaining new strength, and, to the great surprise of the people of Yelisavetgrad, goes to active life "[8, p. 33]. The results of the company's work are beginning to be published in the press.

Active educational work and educational activities were carried out by a member of the society - memoirist, local historian, publicist, teacher Natalia Arkadyevna Braker [11, p. 279].

We learn from archival sources that N. Braker insisted on in-depth development of the theory and practice of public kindergarten in Yelisavetgrad, as the first and 
necessary degree of public education. At the general meeting of the Yelisavetgrad Society for Literacy and Crafts (1912) the educator made a thorough report, which aimed to acquaint members of the society with the basic principles of organization and activities of the Kyiv Society of Kindergartens: "We must take into account the experience of organizing kindergartens which opened its first kindergarten in 1902, and on January 1, 1911 already had two kindergartens, a school for babysitters, a specialty store and a magazine "Preschool education" dedicated to preschool education of children"[5, p. 10].

N. Braker emphasized the necessity to create a permanent special section in the society, which would consider all pedagogical issues, develop programs of public education and upbringing: "To this purpose, it is necessary to involve teachers of various educational institutions, especially since the issue of opening in Yelisavetgrad kindergartens were greeted by the pedagogical community quite favorably "[5, p. 10].

N. Braker emphasized the necessity to involve the public of the city in the organization of public kindergartens and to draw attention of the parents to the urgency to give children the right education that ensures the comprehensive development of the child from an early age. According to her, the organization of kindergarten could be greatly helped by teachers of secondary schools, who in the process of learning and in extracurricular activities encouraged their students to create various products, handouts, collections, which could then serve as material for subject conversations in kindergarten. Natalia Arkadyevna noted that "it is enough to awaken only in children's hearts compassion for other children and it will find a thousand manifestations" [5, p. 11].

N. Braker's proposal was supported and soon a special commission was set up in the Yelisavetgrad Society for the Dissemination of Literacy and Crafts, and she herself became its head.

In addition to extensive educational activities, an important place in society was given to art. From the beginning of the Society's establishment, an Art Section was created, the activity of which was aimed at promoting all kinds of art, which was to promote the development of artistic taste among the general population both in the city and in the region [6, p. 52]. There were art courses at the Society, where members of the section held various classes and gave lectures on art history to all comers. The activity was also manifested in the organization of a wide range of cultural events, among which the most significant was the organization of various exhibitions [6, p. 6]. Thus, the Society for the Dissemination of Literacy and Crafts was the initiator and organizer of the first art exhibitions in the city. During this period, the activities of members of the society, who were the direct organizers of the exhibitions and who managed to attract to the exhibition almost all the artistic treasures of Yelisavetgrad, were able to give it an educational direction [3].

Members of the art section of the Society for the Dissemination of Literacy and Crafts also organized Handicraft Departments at the Yelisavetgrad Agricultural Exhibitions, where they exhibited the best samples of products in this field and at the same time tried to support the existence of handicrafts, whose activities were threatened with extinction. These departments were usually organized by members of 
the art section of the Society, leading local artists-teachers: S. Danyshevsky, I. Zolotarevsky, G. Zusman, F. Kozachynsky, A. Nurenberg, O. Osmerkin, P. Soroka, A. Uzlovskaya and others. When selecting exhibits for the exhibition, they took into account that the presented products could interest the residents of the region and use their further needs, and participation in the exhibition of a master craftsman would be a kind of school for him, where he had the opportunity to get acquainted with other products. examples to evaluate and compare with your own [2]. These exhibitions were staffed by commissions of experienced specialists who determined the quality of the product and pointed out the shortcomings in its production, also gave advice regarding to eliminate them. Thus, the attention of artisans was drawn to the most perfect examples in handicrafts, which contributed to the growth of their professionalism, which in turn affected the quality of industry in the region [6, p. 53]. Sometimes these exhibitions were almost the only opportunity to draw attention to the achievements in this sphere as part of the culture of that time.

At one of such exhibitions the products of the Kompaniivka Art and Craft School of Embroidery and Weaving were presented: towels, napkins, tablecloths, etc. products, and as noted in the press, these works were distinguished by taste, elegance and original drawings [7, p. 3].

Discussion. Opened on the initiative of progressive public figures of the city, the Yelisavetgrad Society for the Dissemination of Literacy and Crafts has played a significant role in the development of vocational education, literacy, science, culture and art in the region.

It became the first public organization to form the city's art center, the Art Section, which included leading local artists and artists from other cities. There were art courses at the section, where practical classes were held and lectures on art were given. The activity of the Art Section was manifested in the organization of various cultural events, among which the most widespread were various exhibitions, which contributed to the development of artistic taste among the general population both in the city and in the region as a whole [2, p. 149].

Result. A significant contribution to the development of educational processes in the region in the second half of the XIX - early XX century was made by educational societies opened on the initiative of progressive public figures of the city. Among the greatest achievements of Yelisavetgrad charity in providing various segments of the population with both basic and special knowledge, the rich and diverse activity of the Yelisavetgrad Society for Literacy and Crafts, which on a charitable basis carried out large-scale educational, pedagogical and educational work: it contributed to the establishment of the educational institutions, it organized Sunday literature reading of progressive literature, it conducted significant educational and organizational and advocacy work among the population and students of educational institutions, organized theater performances, concerts, art exhibitions. Through the efforts of the society, a home for young homeless children, the first kindergartens, a free public library-reading room and a public library were opened in the city. 
Active educational and propaganda activities of the members of the society played a leading role in the spread of education among various segments of the population, contributed to the development of schooling in the region. N. Braker, P. Ryabkov, M. Fedorovsky, V. Khartsiev and others made a significant contribution to reviving the work of the society.

\section{References:}

1. Akimkin, O. M. (2020), Rol' osvitnikh tovarystv u rozvytku pryvatnoyi osvity na Yelysavethradshchyni $v$ druhiy polovyni XIX - na pochatku XX stolittya [The role of educational societies in the development of private education in Yelisavetgrad region in the second half of the XIX - early XX century], Pedahohika ta psykholohiya: napryamy ta tendentsiyi rozvytku v Ukrayini ta sviti: materialy mizhnar. nauk.-prakt. konf. (Odesa, 17-18 kvitnya, 2020 r.), CH. 2, S. 32-35.

2. Bosa, I. O. (2011), Rol' Tovarystva poshyrennya hramotnosti ta remesel u khudozhn'omu zhytti Yelysavethrada na mezhi XIX-XX stolit' [The role of the Society for the Dissemination of Literacy and Crafts in the artistic life of Yelisavetgrad at the turn of the XIX-XX centuries], Ukrayins'ke mystetstvoznavstvo: materialy, doslidzhennya, retsenziyi, Vyp. 11, S. 145-150.

3. Bos'ko, V. M. (2004), Vyznachni postati Stepovoyi Ellady: do 250-richchya zasnuvannya fortetsi Svyatoyi Yelyzavety, mista Yelysavethrada ta 65-richchya utvorennya Kirovohrads'koyi oblasti [Prominent figures of Steppe Greece: to the 250th anniversary of the founding of the fortress of St. Elizabeth, the city of Yelisavetgrad and the 65th anniversary of the Kirovograd region], Kirovohrad: Informatsiyna merezha, $\mathrm{CH}$. $1,376 \mathrm{~s}$.

4. Braker, N. (1928), Mykola Fedorovych Fedorovs'kyy. Pershyy ukrayins'kyy diyach m. Yelysavetu [Mykola Fedorovich Fedorovsky. The first Ukrainian figure of Elizabeth. For a hundred years], Materialy z hromads'koho i literaturnoho zhyttya Ukrayiny XIX i pochatkiv XX stolittya, K.: Derzhvydav Ukrayiny, 1928, Kn. 3, C. 46-49.

5. Doklad komyssyy po ustroystvu narodnykh det·skykh sadov (aprel'-oktyabr' 1912 r.) [Report of the commission on the arrangement of folk kindergartens (April-October 2012], Derzhavnyy arkhiv Kirovohrads'koyi oblasti, F. 304, Op. 1, Spr. 50, 35 ark.

6. Yelisavetgradskoye obshchestvo raspostraneniya gramotnosti i remesel. 1897-1912 gg. Spisok chlenov za 1912 g. Yelisavetgrad Yelisavetgradskogo uyezda Khersonskoy gubernii [Elisavetgrad Society for the Promotion of Literacy and Crafts. 1897-1912 List of members for 1912 Elisavetgrad Elisavetgrad district of Kherson province], Derzhavnyy arkhiv Kirovohrads'koyi oblasti, F. 56, Op. 1, Spr. 1.

7. Otchety o sostoyanii Yelisavetgradskoye remeslenno-gramotnoye uchilishche za 1878-1897 gg. [Derzhavniy arkhív Kírovograds'koî oblastí. Reports on the state of the Elisavetgrad vocational-literate school for 1878-1897], Derzhavnyy arkhiv Kirovohrads'koyi oblasti, F. 61, Op. 1, Spr. 4, 112 ark.

8. Ryabkov, P. Z. (1898), Kratkiy istoricheskiy ocherk Yelisavetgradskogo Obshchestva rasprostraneniya gramotnosti $i$ remesel: 1873-1898 gg. [A brief historical sketch of the Elisavetgrad Society for the dissemination of literacy and crafts: 1873-1898], Yelisavetgrad: Tip. Gol'denberga, 1898. 42 s.

9. Trybuts'ka, O. A. (2012), Yelysavethrads'ke blahodiyne tovarystvo [Yelisavetgrad Charitable Society], Narodne slovo, 26 kvitnya, S. 8.

10.Filonenko, O. V. (2017), Osvita Kirovohradshchyny (Yelysavethradshchyny) v naukovykh refleksiyakh ukrayins'kykh uchenykh (druha polovyna XIX - XX stolittya) [Education of Kirovograd region (Yelisavetgrad region) in scientific reflections of Ukrainian scientists (second half of the XIX - XX centuries)], Kharkiv: Machulyn, $412 \mathrm{~s}$.

11.Filonenko, O. V. (2015), Pedahohichna dumka na Yelysavethradshchyni v pershiy tretyni XX stolittya [Pedagogical thought in the Yelisavetgrad region in the first third of the XX century], Narysy z istoriyi pedahohichnoyi dumky (persha tretyna XX st.), Kirovohrad: RVV KDPU imeni Volodymyra Vynnychenka, 2015, S. 279-310.

12.Filoretova, L. M. (2011), Yelysavethrads'ka hromada [Yelisavetgrad community], Naukovyy chasopys NPU im. Drahomanova. Seriya 6: istorychni nauky. K., Vyp. 9, S. 123-130. 